Zabulonov, Y.L., Burtnyak, V.M., and Odukalets, L.A.

Institute of Environmental Geochemistry, the NAS of Ukraine,

34a, Palladin Ave., 03680, Kyiv, Ukraine; e-mail: igns@i.com.ua

\title{
SYSTEM FOR EFFECTIVE REMOTE CONTROL AND MONITORING OF RADIATION SITUATION BASED ON UNMANNED AERIAL VEHICLE
}

\begin{abstract}
The necessity to create a new technology based on the use of unmanned aerial vehicle (UAV) for controlling the radiation situation in the areas exposed to radiation sources has been justified. The basic specifications of octocopter and developed spectrometric complex have been given. The use of proposed facilities has been showed to enable detection of both spot and distributed sources of radioactive contamination under real conditions.
\end{abstract}

Keywords: nuclear accident, gamma radiation, UAV, spectrometer, radiation safety, and radiation monitoring.

Ukraine is known to have many corporations involved in mining, processing, and storage of raw materials for nuclear fuel. Almost at all stages of their operation, they generate hazardous radioactive waste, dumps, and landfill bearing risk of environment contamination and population exposure to radiation. The nuclear power plants and sources of ionizing radiation used extensively in industry, medicine, agriculture, and research institutions also carry a high potential threat. Today, in Ukraine, radiological situation is complicated and needs to create a rapid response system for radiation control and environment monitoring. Despite all precautions taken in Ukraine and constantly improving reliability of nuclear equipment and technology, at nuclear power plants, there still has remained the risk of emergency situations and accidents with release of radionuclides into environment. Therefore, the state that has nuclear power engineering facilities must be ready to respond to such an accident. This will significantly reduce the severity of accident con-

(C) ZABULONOV, Y.L., BURTNYAK, V.M., and ODUKALETS, L.A., 2017 sequences and the costs of responding to the danger, which is economically advantageous as compared with the cost of overcoming its consequences in the do-nothing case [1].

Today, in our country, there are no modern logistic facilities enabling effective control of radiation situation in the areas of radiation exposure from various natural and man-made radiation sources. This situation significantly aggravates the risk to public health and environment and adversely affects the Ukraine's international image.

The development of unmanned aircraft and miniaturization of electronic components have enabled to arrange gamma radiometric and spectrometric equipment in compact unmanned aerial vehicle (UAV) [2]. Due to their low cost and capability of being adapted to various needs, unmanned vehicles on multi-copter platforms have been applied to localization of radiation sources and detailed mapping of polluted areas. Multicopter UAV as a platform for aero-gamma-spectrometric apparatus has several advantages: the ability to fly at a height of $1 \mathrm{~m}$ at a speed of $3.6 \mathrm{~km} / \mathrm{h}$; automated takeoff, survey, and landing; and the possibility to get detailed survey of 
anomalies detected by hovering over them or by landing for taking spectra, to take pictures of vertical surfaces by using gyro-stabilized location spectrometer. The aero-gamma-spectrometric system is selected depending on the task that must be done since various systems have their advantages and limitations.

The researcher team of the Institute of Environmental Geochemistry of the NAS of Ukraine has developed hardware and software for detecting and counting places of interim radioactive waste localization to assess the need and feasibility of their reburial. An automated system for rapid response to radiation control and environmental monitoring has been created based on ASPEC-O UAV [3].

\section{The Main System Functions and Components}

The ASPEC-O system consists of ground and on-board units. The on-board component of the system is designed for measuring and collecting gamma radiation spectra identified by geographic coordinates, altitude, pressure, and temperature of the earth's surface area surveyed. The ground component of spectrometric complex is a computer system processing and keeping the database of spectrometric information coming from the air remote complex, identifying areas of radioactive contamination, measuring the gamma radiation spectral composition and exposure dose, searching and determining the coordinates of gamma radiation point sources. The complex also provides visualization, mapping of dose distribution, and filing of radiation monitoring data.

An octocopter-type UAV was selected to carry the measuring equipment (Fig. 1). It is a shortrange helicopter-type remotely controlled automatic airborne vehicle. The octocopter has dimensions $1040 \times 1040 \mathrm{~mm}$, and a load capacity of up to $7.5 \mathrm{~kg}$. Flight speed of unloaded device can reach up to $10 \mathrm{~m} / \mathrm{s}$, airborne time is $20-25 \mathrm{~min}$ utes. Flying altitude is $1-300 \mathrm{~m}$.

A system for detecting gamma radiation, which consisted of five typical scintillation blocks BDEG04 was used as a spectrometer, the key element in measuring systems [3]. However, after a series of test flights, the BDEG-04 units because of their low resolution were replaced by $10 \mathrm{~S} 10 / 3$ Amcryc detector. This detector is based on Nai (Tl) crystal, size Ø63 × $63 \mathrm{~mm}$, and R1307-type PEC manufactured by Hamamatsu, its resolution is $6 \%$. One of the main technical parameters of the spectrometer is its weight, it shall not exceed $7.5 \mathrm{~kg}$. The key features of the spectrometer are as follows:

Base detector. Amcryc

Dimensions of base detector, $\mathrm{mm} \ldots \ldots \ldots \ldots . \quad \varnothing 63 \times 63$

Weight, g........................... 850

Number of base detectors in the system ...... 5

Range of photon radiation energy measured, $\mathrm{keV}$ 0,5-3000

Measurement range of equivalent dose rate (EDR),

$\mathrm{mSv} / \mathrm{h}$. . . .

$0,1-5000$

Limit of permissible basic relative error of DER

measurement, \% ......................

Anisotropy sensitivity detection unit (about the

longitudinal axis), $\% \ldots \ldots \ldots \ldots \ldots \ldots$

Dimension of detection unit:

diameter, $\mathrm{mm} \ldots \ldots \ldots \ldots \ldots \ldots \ldots \ldots \ldots$

length, $\mathrm{mm} \ldots \ldots \ldots \ldots \ldots \ldots \ldots \ldots \ldots$

weigh, $\mathrm{kg} . \ldots \ldots \ldots \ldots \ldots \ldots \ldots \ldots$
20

15

300

300

6,5
Block diagram of the detection system is showed in Fig. 2.

Spectrometer parameters, dimensions, and weight enable to install it on octocopters. Such «detector» allows the operator to exercise real-time control over unit sensitivity by turning on/off

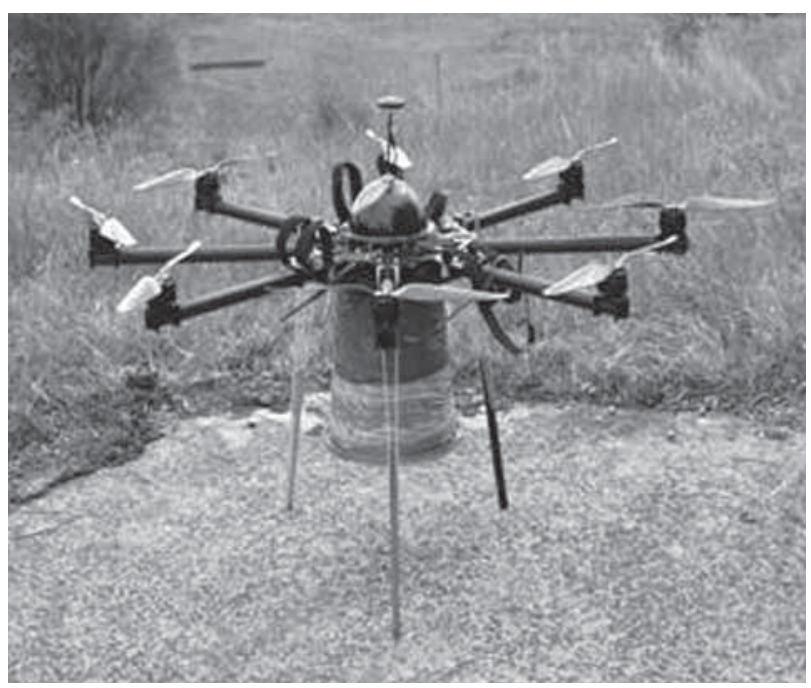

Fig. 1. UAV with gamma spectrometric complex 


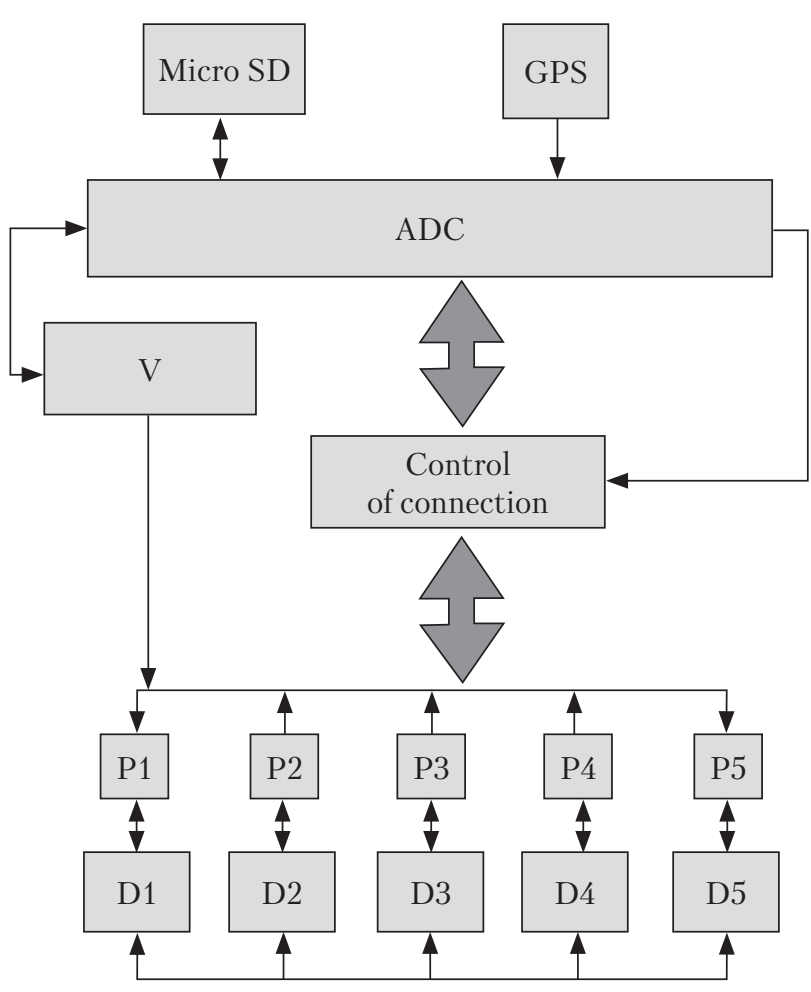

Fig. 2. Configuration of UAV detector (D1-D5 - detectors; P1-P5 - preamplifiers; V - high-voltage power source)

one of the five detectors. In the surveyed areas with high radiation activity it is advisable to turn off one or more base detectors. And vice versa, if radiation activity in the area is low, connecting additional base detectors increases the statistical significance of measurements.

The positioning system (determination of coordinates) of the measuring complex is based on GPS satellite navigation sensor. More visual details of the area surveyed is provided by a video camera included into the equipment and installed on the UAV board. Data from the gamma radiation detection unit, GPS-receiver, and video camera are recorded on MicroSD and transmitted to the ground base station via radio channel.

The equipped UAV includes the following:

+ Base station;

+ Remote antennas;

+ Set of transmitting equipment;

+ PC (laptop);
+ Spectrometric equipment;

+ Radio-controlled UAV; and

+ Vehicle.

\section{Peculiarities of Radiation Control Using UAVs}

The method of aero gamma survey using UAVs foresees that the airborne vehicle equipped with spectrometer system flies over the area surveyed along the routes set in the Gauss-Kruger coordinate system (Fig. 3). Grid is a rectangle with a step sufficient for a given accuracy. For getting detailed maps of contamination the grid in is a rectangular with a horizontal step of $100 \mathrm{~m}$. The UAV speed is $10 \mathrm{~m} / \mathrm{s}$, at $30 \mathrm{~m}$ altitude. Information is recorded every second in a specialized onboard computer and transmitted to the ground station via WiFi communication channel. During the flight, the screen of ground station displays in real-time mode the following information: the aircraft coordinates received automatically from the GPS satellite navigation system unit, the spectral composition of radioactive contamination attributed to real objects; the radiation dose and power.

The onboard part of the system performs the following functions:

+ Cyclic measurements (period $1 \mathrm{~s}$ ) of gamma radiation spectra of radionuclides of natural and man-made origin contained in the soil or on the surface of the surveyed areas;

+ Time matching of the received spectra with determined topographic coordinates of the place of measurement;

+ Time matching of the received spectra with determined height of the measurements in order to take into account the effect of gamma radiation weakening in the air stratum for processing information obtained by the ground equipment software;

+ Creating and recording a file containing the measurement data on the onboard computer MicroSD;

+ Use of traffic files for respective data processing by the ground equipment software. 


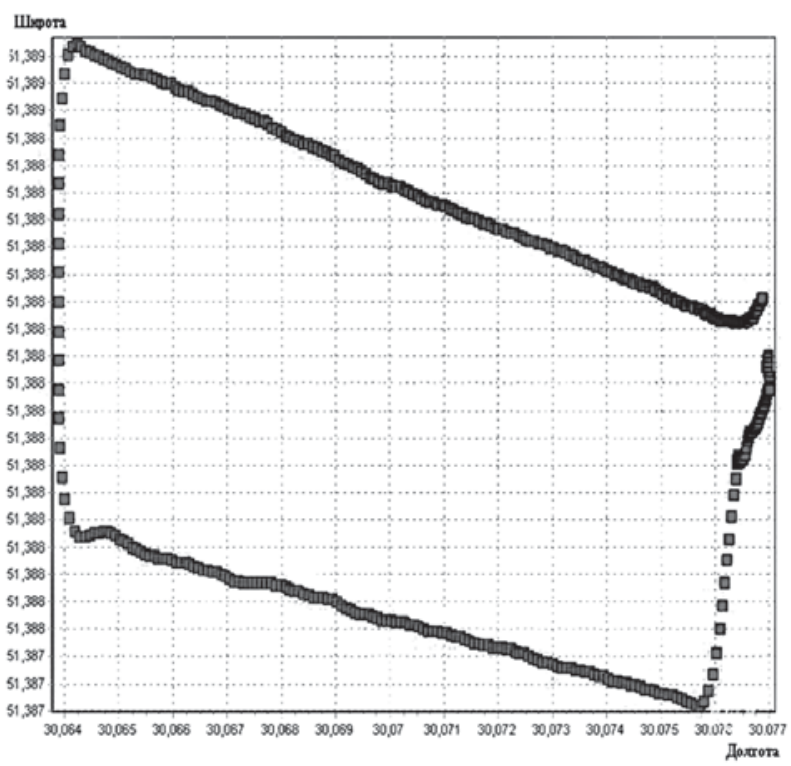

Fig. 3. Flight track

The mentioned functions are the main functions of the complex, which ensure the implementation of its main purpose, i.e. the formation of an array of gamma radiation spectra with their reference to the location and altitude.

There are several auxiliary functions to support the basic functions:

+ Television surveys of the area with recording video information on the MicroSD flash memory;

+ Functional self-control of equipment during the operation.

Thus, after remote measurements from the UAV board, an array of primary measured information on the activity of radionuclides contained in the soil or on the surface of the surveyed area with reference to flight altitude (weakening of radioactivity in the air stratum) and topographic coordinates is formed on the MicroSD.

The primary measurement information is 1024channel gamma-ray spectra (Fig. 4) in the range of energies from 50 to $3000 \mathrm{keV}$.

The system ground equipment after processing the array of primary measurement information enables the following [4]:

+ To create a two-dimensional picture of the earth surface gamma radiation field;

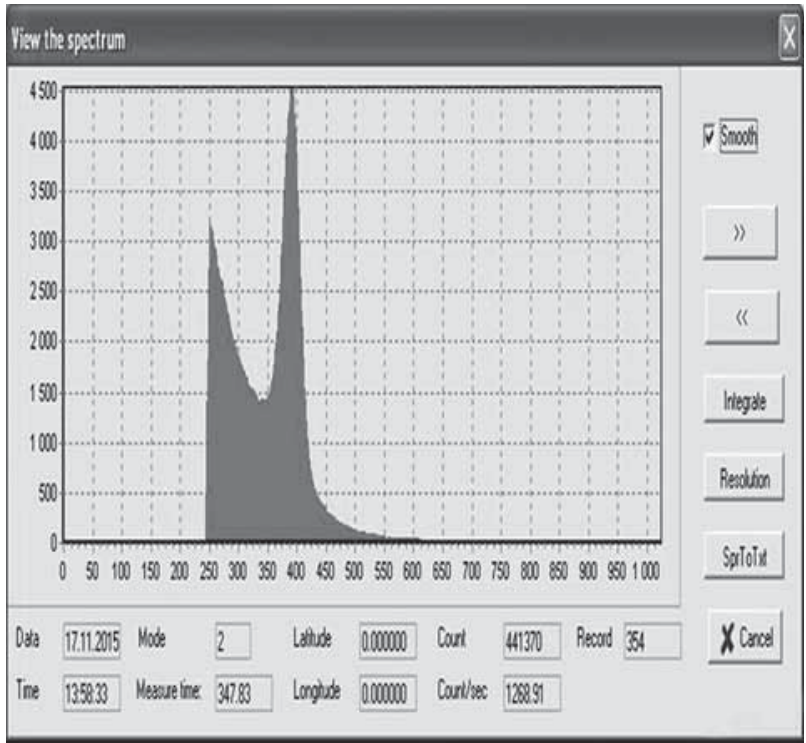

Fig. 4. Integral gamma-radiation spectrum

+ To detect the point and free extended radiation sources of low active gamma radiation sources;

+ To identify the radionuclide composition of the source;

+ To measure the surface density of radionuclide activity (after-accident radiation trace);

+ To determine the radiation source coordinates with an accuracy of 1-10 $\mathrm{m}$ (depending on the UAV speed and altitude).

Hence, the UAV-based multifunctional measuring complex enables to solve a wide range of assignments related to radiation control.

The results of processing of aero gamma-spectrometric data obtained at the Department of Nuclear Physics Technologies of the IEG of the NAS of Ukraine are showed in Figs 5-6. Fig. 5 features two-dimensional fields of radioactive contamination of Sandy Plateau site of the Chornobyl NPP Exclusion Zone. ESRI ArcGIS software [5] was used to process aero-gamma survey. For interpolation, the Empirical Bayesian Kriging method applied. Based on the number of impulses in the Cs-137channel, the spatial distribution of gamma radiation has been obtained. Fig. 6 shows the detected radioactive contamination 


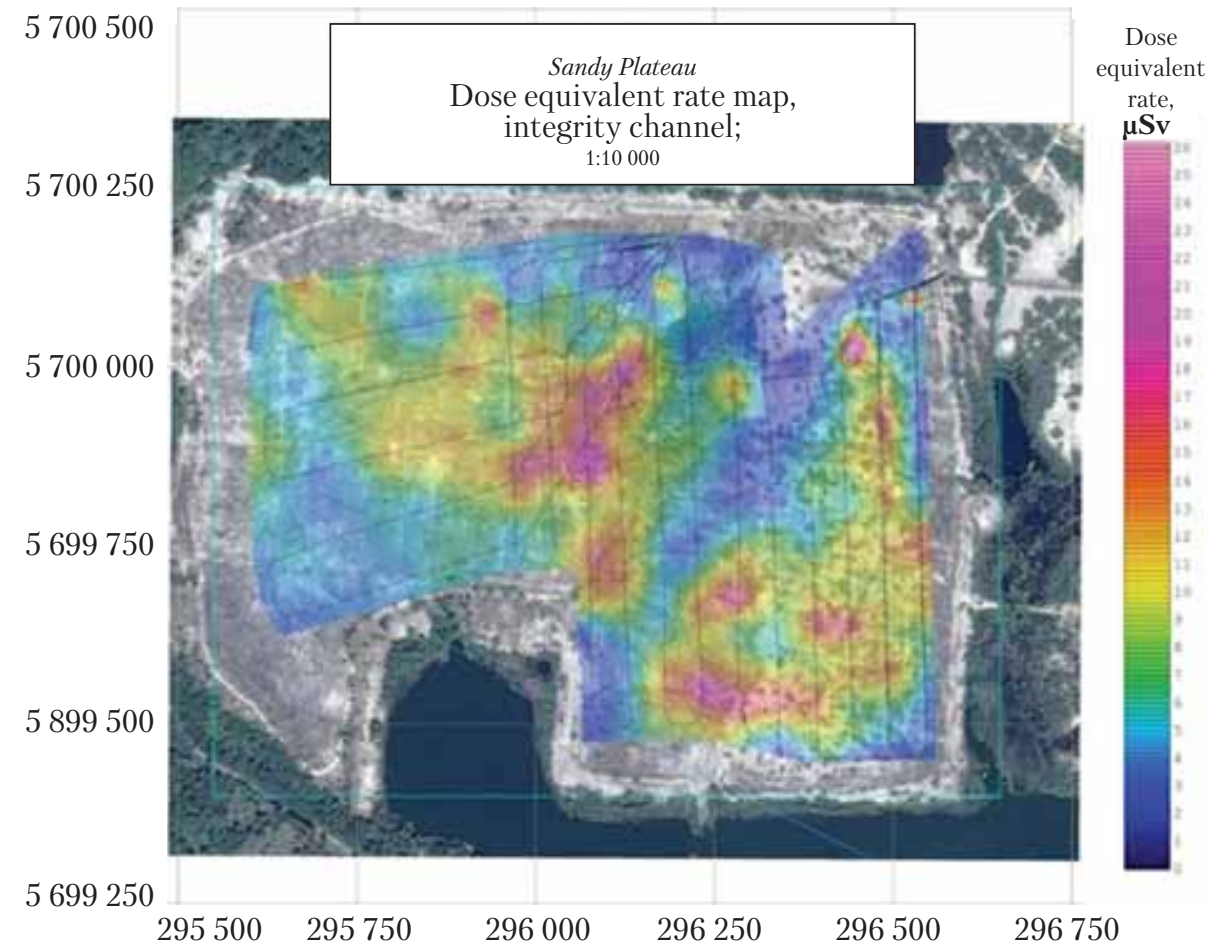

Fig. 5. Radioactive contamination (radioactive burial grounds) of the Sandy Plateau site in the Chornobyl NPP Exclusion Zone

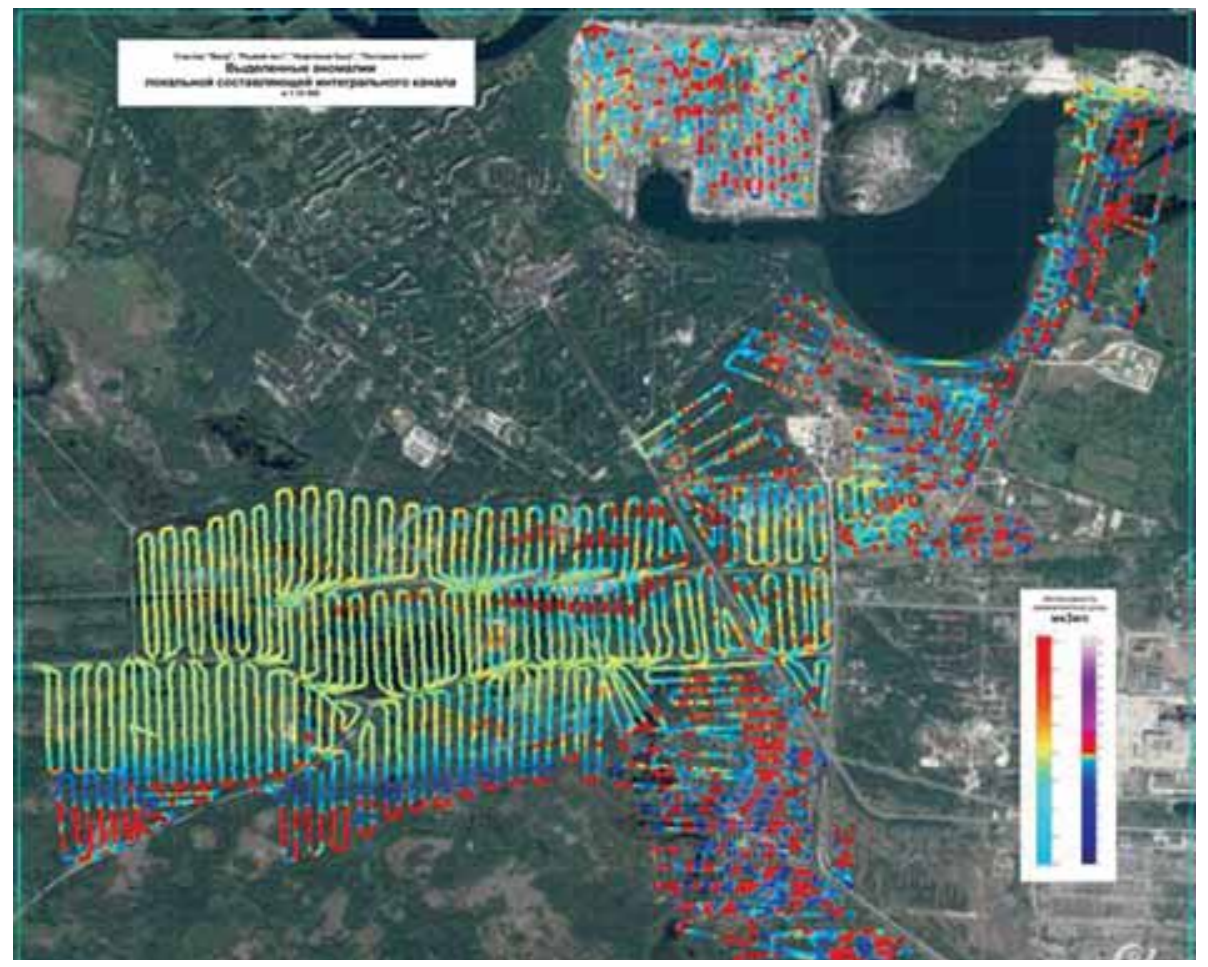

Fig. 6. Radioactive contamination detected along the UAV routes 
along the UAV routes, including a $20 \mathrm{~m}$ wide contaminated band along the UAV route without interpolation.

\section{CONCLUSIONS}

The designed ASPEC-O system enables remote measurements of gamma radiation equivalent dose rate and determination of radionuclide composition of radiation trace and surface density of radionuclide activity based on gamma radiation spectrum analysis. The UAV-based aero-gamma spectrometry system enables high-resolution mapping of radiation contamination without any risk to human health.

The proposed system is the first one in Ukraine to carry out the whole cycle of works on detecting local inhomogeneity in the soil, searching for and detecting radioactive sources, and measuring the contamination level.

\section{REFERENCES}

1. B IAEA-TECDOC-1092. Generic procedures for monitoring in a nuclear or radiological emergency. International Atomic Energy Agency. Vienna. June 1999. $305 \mathrm{p}$.

2. Connor D., Martin P. G., Scott T. B. Airborne radiation mapping: overview and application of current and future aerial systems. International Journal of Remote Sensing. Vol. 37, Iss. 24. 2016.

3. Zabulonov Y.L., Burtnyak V.M., Zolkin I.O. Aerogammaspectrometric survey in the Chernobyl exclusion zone on the basis of an octopopter-type UAV. Questions of Atomic Science and Technology. 2015. 5(99): 163-167 [in Russian].

4. Lysychenko G.V., Zabulonov Y.L., Makarets N.V. Results of model and field experiments on the detection of lowintensity sources of radioactive ionization. Proceedings of the Pukhov Institute for Modelling in Energy Engineering of NAS of Ukraine. Kyiv, 2005. 96-100 [in Russian].

5. ArcGIS for Desktop Software. URL: http://www.esri.com/ arcgis/about-arcgis. (Last accessed: 07.04.17).

Recieved 31.01.17

\author{
Ю.Л. Забулонов, В.М. Буртияк, Л.А. Одукалещь \\ Державна установа «Інститут геохімії \\ навколишнього середовища НАН України», \\ пр-т Палладіна, 34а, Київ-142, 03680, igns@i.com.ua \\ СИСТЕМА ДЛЯ ОПЕРАТИВНОГО \\ ДИСТАНЦІЙНОГО КОНТРОЛЮ \\ ТА СПОСТЕРЕЖЕННЯ ЗА РАДІАЦІЙНОЮ \\ ОБСТАНОВКОЮ НА БАЗІ БЕЗПІЛОТНОГО \\ ЛІТАЛЬНОГО АПАРАТУ
}

Обгрунтовано необхідність створення нових технічних засобів для контролю за радіаційною обстановкою на територіях радіаційного впливу джерел іонізуючого випромінювання на базі безпілотного літального апарата (БПЛА). Наведено основні технічні характеристики БПЛА типу октокоптер та розробленого спектрометричного комплексу для системи. Показано, що застосування створених засобів дає змогу в реальних умовах дистанційно виявляти як точкові, так і розподілені джерела радіоактивного забруднення.

Ключові слова: ядерно-радіаційна аварія, гамма-випромінювання, БПЛА, спектрометр, радіаційна безпека, радіаційний моніторинг.

\section{Ю.Л. Забулонов, В.М. Буртняк, Л.А. Одукалеи, \\ ГУ «Институт геохимии окружающей среды НАН Украины», пр-т Палладина, 34а, Киев, 03680, Украина, e-mail: igns@i.com.ua СИСТЕМА ДЛЯ ОПЕРАТИВНОГО ДИСТАНЦИОННОГО КОНТРОЛЯ И НАБЛЮДЕНИЯ ЗА РАДИАЦИОННОЙ ОБСТАНОВКОЙ НА БАЗЕ БЕСПИЛОТНОГО ЛЕТАТЕЛЬНОГО АППАРАТА}

Обоснована необходимость создания новых технических средств для контроля за радиационной обстановкой на территориях радиационного влияния источников ионизирующего излучения на базе беспилотного летательного аппарата (БПЛА). Приведены основные технические характеристики БПЛА типа октокоптера и разработанного спектрометрического комплекса для системы. Показано, что применение созданных средств дает возможность в реальных условиях дистанционно выявлять как точечные, так и распределенные источники радиоактивного загрязнения.

Ключевые слова:ядерно-радиационная авария, гамма-излучения, БПЛА, спектрометр, радиационная безопасность, радиационный мониторинг. 